[AMfrican Journal. of Science, Vol. 281, March, 1981, P. 247-263]

\title{
STRATIGRAPHIC AND ECOLOGIC IMPLICATIONS OF LATE PRECAMBRIAN MICROFOSSILS FROM UTAH
}

\author{
ANDREW H. KNOLL*, NICHOLAS BLICK** and \\ STANLEY M. AWRAMIK**
}

\begin{abstract}
Abundant and well preserved microfossils have been discovered in black shales and siltstones of the glaciogenic upper Precambrian Mineral Fork Formation near Salt Lake City, Utah. The rocks are interpreted to have been deposited close to an ice margin in a shallow, restricted marine embayment during glacial retreat.

Several distinct morphotypes are discernible, but following Moorman (1974), we interpret most of these as stages in the life cycle of a single planktonic, endosporulating alga, Bavlinella faveolata (Shepeleva) Vidal. The low taxonomic diversity of this assemblage, coupled with the large population size and almost complete dominance by Bavlinella, suggests an ecologically stressed enviromment. The source of this stress was probably the melting glacier.

On the basis of stratigraphic position and lithological correlation with a radiometrically dated sequence in Washington, the Mineral Fork Formation has been considered to be about $800 \mathrm{~m}$.y. old; however, most well dated occurrences of Bavlinella are in rocks of Vendian (650-570 m.y.) age. The presence of Bavlinella faveolata in Mineral Fork strata raises significant questions concerning both the stratigraphic range of this presumed Vendian index fossil and the timing of Late Precambrian glaciation in the North American Cordillera.
\end{abstract}

\section{INTRODUCTION}

Stromatolites and the silicified remains of stromatolitic microorganisms constitute the fossil evidence of Precambrian life most familiar to North American scientists. Organic rich cherts have yielded much useful data on the morphologies of early organisms, especially cyanobacteria, and observed temporal variation in the shapes and microstructural patterns of stromatolites has been used to establish an empirically successful framework for the biostratigraphic zonation of Proterozoic rocks. While the great importance of these lines of evidence cannot be disputed, it is fair to say that the portrait of Precambrian life they provide is incomplete. The great emphasis placed on stromatolites and stromatolitic microbiotas has skewed paleobiological inquiry toward carbonate facies and, thus, a limited range of marine environments.

For the past two decades, Soviet and European micropaleontologists have been engaged in the palynological analysis of Proterozoic detrital rocks (Timofeev, 1959, 1969, 1973; Roblot, 1963, 1964; Volkova, 1968; and many others), and more recently, North American paleontologists have begun to investigate siltstones and shales for their possible microfossil content. In 1968, Licari and Cloud discovered organically preserved fossils of presumably planktonic algae in shales from the Hector Formation of Alberta, work that was continued by Moorman (1974). Elsewhere in North America, clastic facies microfossils have been reported from late Precambrian strata of Alaska (Allison and Moorman, 1973), British Columbia (Javor and Mountjoy, 1976); Utah (Cloud, Moorman, and Pierce, 1975; Hofmann, 1977), Arizona (Ford and Breed, 1973; Bloeser

* Department of Geology, Oberlin College, Oberlin, Ohio 44074

** Department of Gcological Sciences, University of California, Santa Barbara, California 93106 
and others, 1976), Newfoundland (Hofmann, Hill, and King, 1979), and Tennessee (Knoll and Keller, 1979). Perhaps the oldest clastic facies microbiotas known at present from North America are those from the 1100 to 800 m.y. old Little Dal Group of Northwestern Canada (Hofmann and Aitken, 1979) and from 1400 m.y. old shales of the lower Belt Supergroup in Montana (Horodyski and Bloeser, 1978). Both these Riphean deposits also contain large carbonaceous ribbons which may be the remains of megascopic multicellular algae (Walter, Oehler, and Oehler, 1976; Hofmann and Aitken, 1979).

Unlike the silicified remains of algal mat microbes, most of the microfossils found in Precambrian argillites cannot be assigned confidently to extant taxa. Thus, most clastic facies microbial fossils must be classified as acritarchs (Vidal, 1976a). In spite of the unavoidable taxonomic uncertainty, there are good reasons to study clastic facies microbiotas.

1. Most Precambrian sediments are not carbonates (Ronov, 1968); detrital sedimentary rocks represent a wide range of environments whose constituent biotas might be expected to differ significantly from those of stromatolitic carbonate habitats.

2. Because of environmental restrictions on silicified microorganisms in algal carbonates (Knoll and Golubic, 1979), shale facies microbiotas are perhaps better assemblages among which to search for evidence of Precambrian evolutionary innovations. Fossils preserved in shale have provided some of the least debatable evidence for early eukaryotes (Schopf and Oehler, 1976) and have prompted speculation about gigantism among cyanobacterial populations prior to the rise of nucleated organisms (Peat and others, 1978).

3. Like stromatolites in calcareous facies, sphaeromorph acritarchs preserved in Precambrian detrital rocks can be stratigraphically useful (Timofeev, 1959, 1969, 1973; Vidal, 1976a).

In this paper, we will discuss an assemblage of organically preserved microfossils discovered in siltstones and black shales of the upper Precambrian Mineral Fork Formation, located in the central Wasatch Mountains, approx $25 \mathrm{~km}$ southeast of Salt Lake City, Utah (fig. 1). We hope to demonstrate that these fossils can contribute to our understanding of both ecological and stratigraphic aspects of late Precambrian Cordilleran geology.

\section{THE MICROFOSSIL ASSEMBLAGE}

Fossil microorganisms are extremely abundant in Mineral Fork rocks (approx $10^{5}$ individuals per $\mathrm{cm}^{3}$ of sediment), and a variety of morphologies are evident. Most common are simple unornamented unicells. These range in size from 2 to $24 \mu \mathrm{m}$ in diameter, but most fall in the range of 5 to $15 \mu \mathrm{m}$. A histogram of size frequency for a sample population of 600 cells (fig. 2) illustrates that this distribution is unimodal with a slight skew to the right (mean $=8.9 \mu \mathrm{m}$; standard deviation $=3.6 \mu \mathrm{m}$ ). a size frequency distribution that is common for monospecific algal populations (Prakash and others, 1972; Knoll, Barghoorn, and Awramik, 


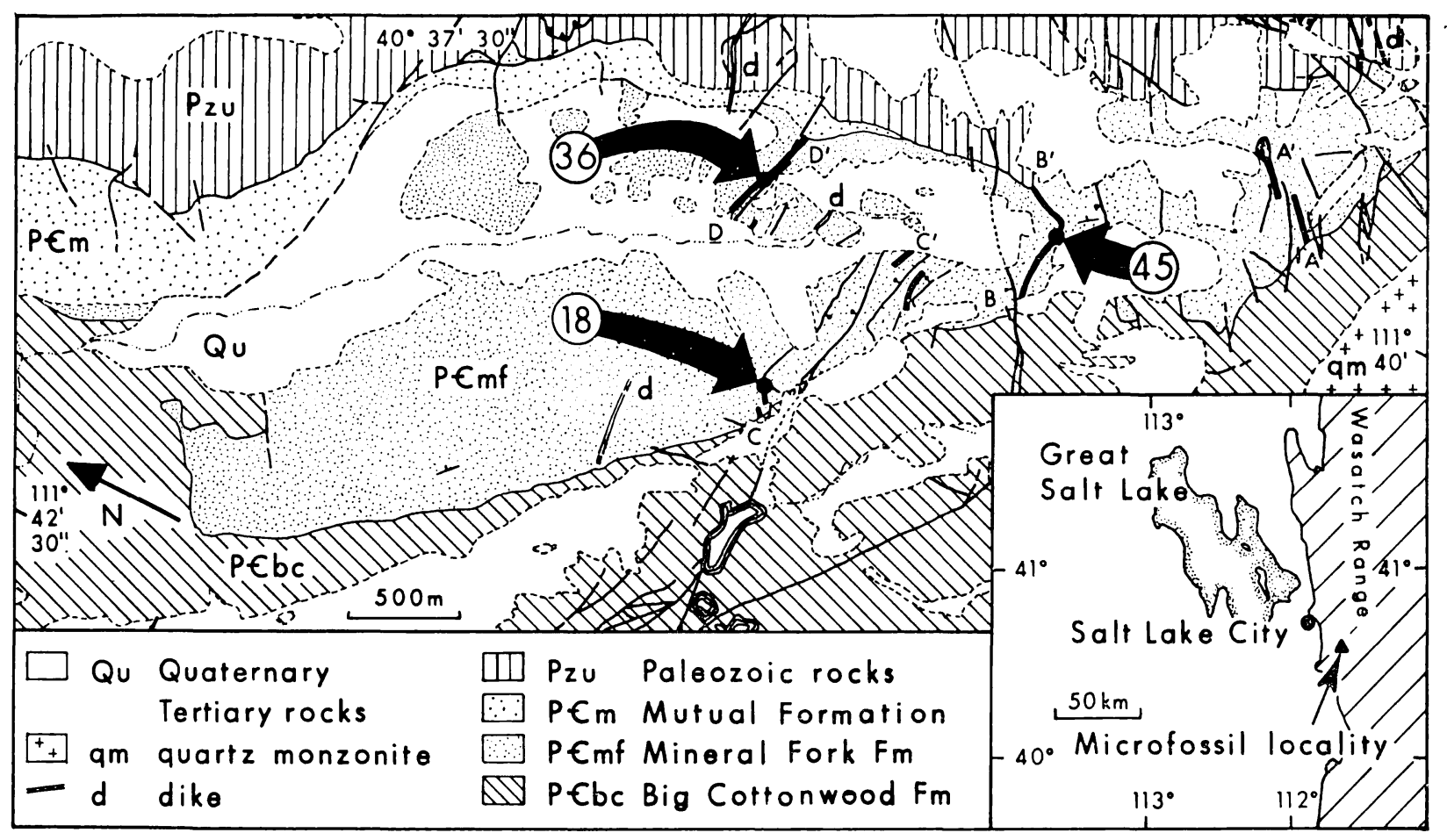

Fig. 1. Geologic setting of microfossil-bearing samples MF 18, 36, and 45 in the Mineral Fork Formation, Mineral Fork of Big Cottonwood Canyon in the Wasatch Mountains, northwestem Utah. Gcologic map simplified and modified slightly from Critienden (1965a, b). $\mathrm{AA}^{\prime}, \mathrm{BB}^{\prime}, \mathrm{CC}^{\prime}$, and $\mathrm{DD}^{\prime}$ refer to measured sections shown in figure 4. 
1978). Psilate unicells may occur singly or in clusters of up to several dozen cells. A single cluster often contains individuals of widely varying sizes (pl. 1), but, in general, smaller cells are more likely than larger individuals to be found in groups. In a few cases one can see evidence of cell division in the forms of dyads or quartets of closely compressed daughter cells having clear cleavage planes (pl. 1).

The most distinctive organic entity in the Mineral Fork assemblage is the morphotype referred to as Bavlinella faveolata (Shepeleva) Vidal (1976a). Bavlinella individuals range from 6 to $27 \mu \mathrm{m}$ in cliameter (mean $=13.7 \mu \mathrm{m}$, standard deviation $=4.0 \mu \mathrm{m}, \mathrm{n}=200$; see fig. 3 for size frequency distribution). Actually, each "individual" consists of several dozen to well over one hundred micron-sized cells packed together in a raspberry-like multisphere. Inevitably, discussion of Bavlinella faveolata prompts comparison to pyrite framboids and raises questions concerning the biogenicity of this morphotype. Cloud, Moorman, and Pierce (1975),

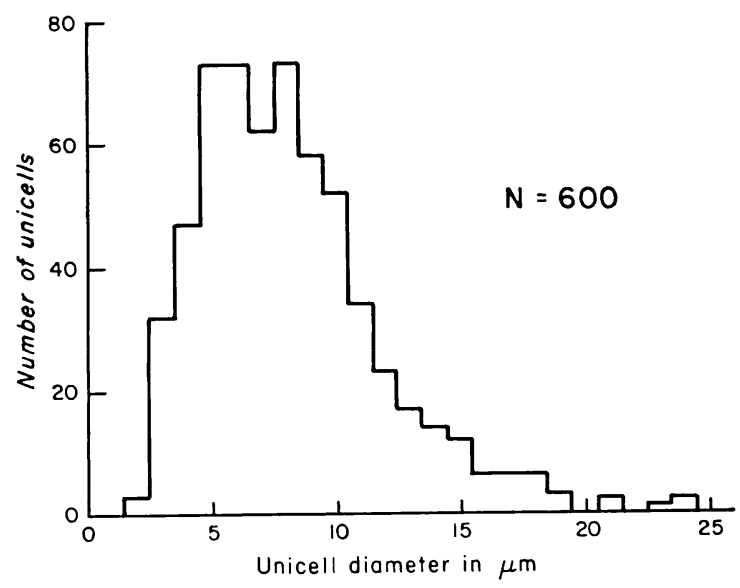

Fig. 2. Size frequency distribution of unicells from the Mineral Fork Formation.

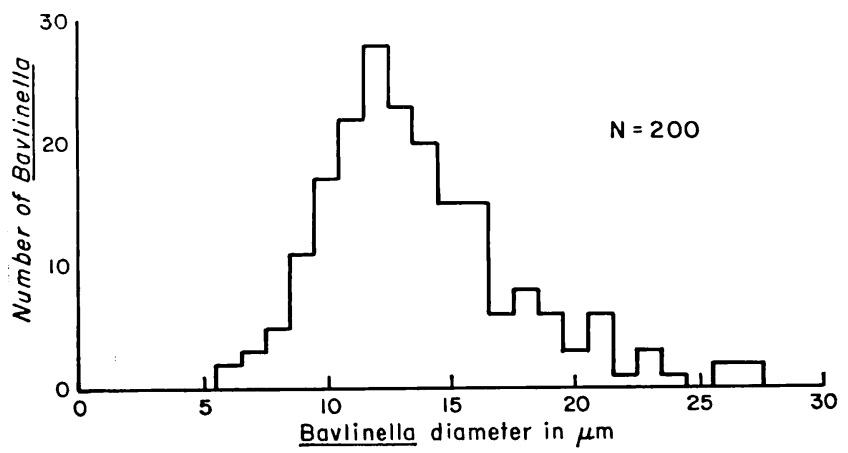

Fig. 3. Size frequency distribution of Bavlinella faveolata multispheres in the Mineral Fork Formation. 
PLATE 1
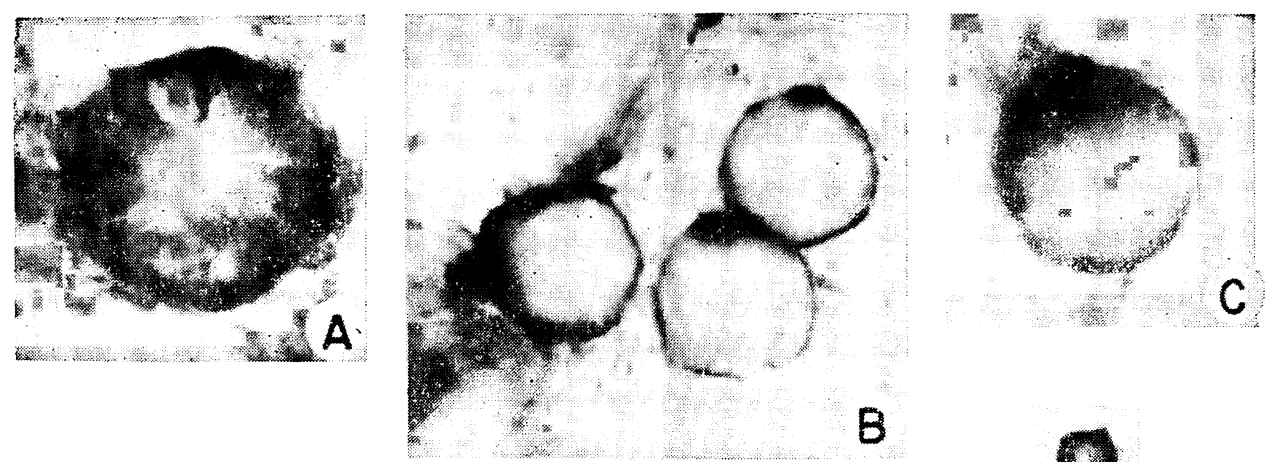

B
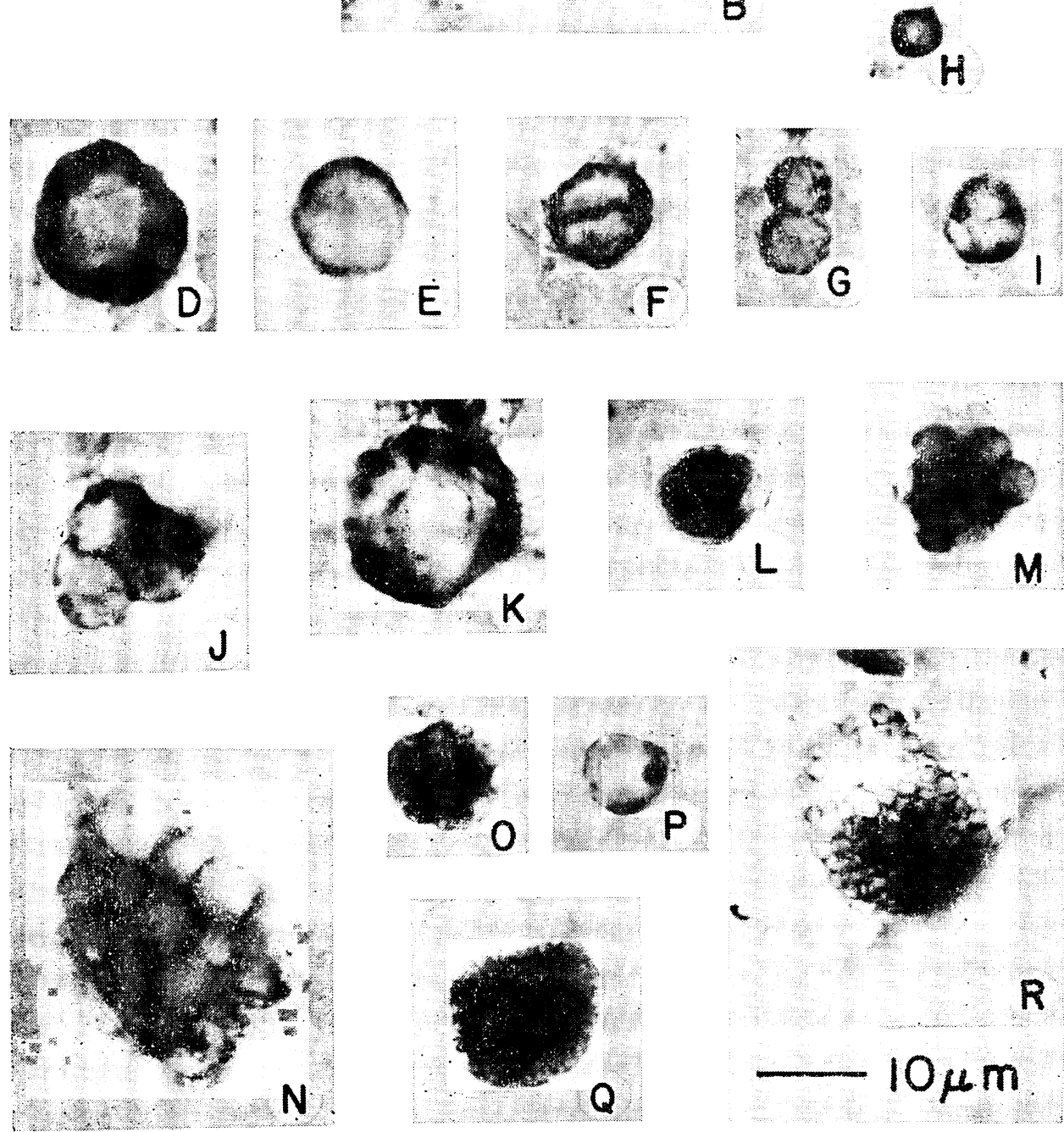

Mineral Folk microfossils from locality MF36. All photomicrographs are from thin sections and are reproduced at the same scale. (A-E, H) Spherical morphotypes showing variety in size and surficial features. (F) Dyad with well developed cleavage plane. (G) Pair of cells, cleavage plane indistinct. () Multiple cells (3, possibly 4) tightly compressed within vesicle. (J) Triad. (K) Sphere within sphere. (L) Pluricellular aggregate (?baeocytes) within well defined, thick vesicle. Rupture to right may be degradational or diagenetic. (M-O) Pluricellular aggregates (bacocytes) possibly different developmental stages in Bavlinella (Q). (P) Compound structure. Note partially degraded internal contents at right. (Q) Bavlinella. (R) Bavlinella in which individual elements are partially disaggregated. 
Vidal (1977), and others have pursued this problem in some detail, and we will not reiterate all their arguments here; however, in order that the Mineral Fork microorganisms not be confused with morphologically similar mineral growths, we list briefly several ways in which Bavlinella differs from framboidal pyrite: (1) the Mineral Fork Bavlinella specimens are composed of organic matter and contain no pyrite (note in the accompanying illustrations that transmitted light passes through the specimens; they are not opaque like pyrite); (2) the taxon Bavlinella faveolata has a discrete time range; it is not found in acritarch assemblages older than Late Riphean or younger than Cambrian no matter how rich in pyrite they may be (Vidal, 1977); and (3) in the Mineral Fork microfossil assemblage, one finds a range of morphologies that are transitional between the Bavlinella multispheres and clusters of sphaeromorphic unicells (see Moorman, 1974, and discussion below). Pyrite framboids can and do resemble certain types of microorganisms, but the Mineral Fork Baylinella represents a biological organization.

Basing her discussion on Beck's (1963) description of endosporulation in the modern cyanobacterium Pleurocapsa fuliginosa Hauk, Moorman (1974) interpreted a similar range of morphologies found in late Precambrian black shales of the Hector Formation, Alberta, as different stages in the life cycle of a single endosporulating species. (See Moorman, 1974, p. 530-535 and text-fig. 3 for a detailed description of this life cycle.) More recently, Waterbury and Stanier (1978) have detailed patterns of growth and development for all six modern genera of the Pleurocapsales. Their analysis of living cyanobacteria supports the interpretations of Moorman, although the genera Xenococcus and Dermocarpa appear to be closer analogues to the Hector fossils than is Pleurocapsa, itself.

Following Moorman, we interpret many (but not all) of the various unicells, dyads, aggregates, and Bavlinella specimens found in the Mineral Fork sediments as stages in the life cycle of a single taxon. We find all the various morphologies figured by Waterbury and Stanier in their discussions of Dermocarpa and Xenococcus and in addition find intermediate morphologies that link the well-defined Bavlinella multispheres to other members of the assemblage. Certainly, the Mineral Fork plankters exhibit a life cycle very similar to that of modern Pleurocapsalean genera, although the living morphological analogues generally grow epiphytically or attached to some other surface (Geitler, 1932). Whatever the true affinities of the Mineral Fork Bavlinella organism, the important point is that several distinct morphologies apparent in the assemblage represent a single species.

This single taxon completely dominates the Mineral Fork assemblage. A few taxonomically distinct sphaeromorphs have been encountered, but these are exceedingly rare. It is true that (A) some members of the original Mineral Fork plankton community were probably not preserved, and (B) the population of unicellular microfossils is probably more heterogeneous than the unimodal size frequency distribution 
would suggest (that is, the morphological simplicity of the microfossils may mask their true taxonomic diversity); however, all caveats aside, the Mineral Fork microbiota is an extraordinarily low-diversity assemblage.

This contrasts strongly with late Precambrian acritarch assemblages from other parts of the world that contain as many as two dozen distinct morphotypes (Vidal, 1976a). Such paleocommunity characters as large population size, low diversity, and a high degree of dominance by a single taxon have generally been interpreted by invertebrate paleontologists as indicators of unstable or stressed environments (Ziegler and others, 1974, p. 2.7). For groups other than benthic marine invertebrates, the relationship between stability and diversity is not a simple one (Whittaker, 1975, p. 101-103); however, stressed environmental conditions do appear to correlate well with high dominance/low diversity planktonic algal communities. An extreme example of algal response to stress would be the blooms that occur when unusually high levels of nutrients enter an aquatic ecosystem.

The community structure of the Mineral Fork microfossils, particularly when contrasted to other much more diverse assemblages known from late Precambrian rocks, suggests that the Utah microorganisms grew under unusual environmental conditions, most likely in a stressed habitat. The sedimentary rock sequence of the Mineral Fork Formation casts light on the nature of this environment.

\section{ENVIRONMENT OF DEPOSITION}

In the central Wasatch Mountains, the Mineral Fork Formation constitutes the basal unit of a thin upper Precambrian and Paleozoic sequence that was deposited on a platform east of the Cordilleran miogeocline (Crittenden and others, 1971). A lenticular deposit, the Mineral Fork sits unconformably on quartzite and shale of the Big Cottonwood Formation and is, in turn, unconformably overlain by predominantly quartzitic sediments of either the Mutual or the Tintic formations, depending on locality (Crittenden, Sharp, and Calkins, 1952). The Mineral Fork Formation consists of as much as $790 \mathrm{~m}$ of rusty weathering, black or dark gray, quartzose diamictite, graywacke, siltstone, shale, and sandstone, along with minor amounts of conglomerate and dolomite (pl. 2-A). Diamictite constitutes approx 70 to 75 percent of the total sequence, while a further 15 to 25 percent is rhythmically interbedded sandstone and laminated siltstone (pl. 2-B and fig. 4). Individual rhythmite units are as much as $50 \mathrm{~m}$ thick.

A glacial origin for the Mineral Rock Formation was first published by Hintze (1913) on the basis of the till-like appearance of much of the section. More recently, Crittenden and his colleagues (1952, 1971, 1972), Varney (1976), and Ojakangas and Matsch (1976) have concurred in this interpretation. Condie (1967) suggested a subaqueous mudflow origin for the diamictite but did not rule out the possibility of contemporaneous glaciation. The minority viewpoint that the Mineral Fork Formation is 
PLATE 2

Field setting of microfossiliferous siltstone.

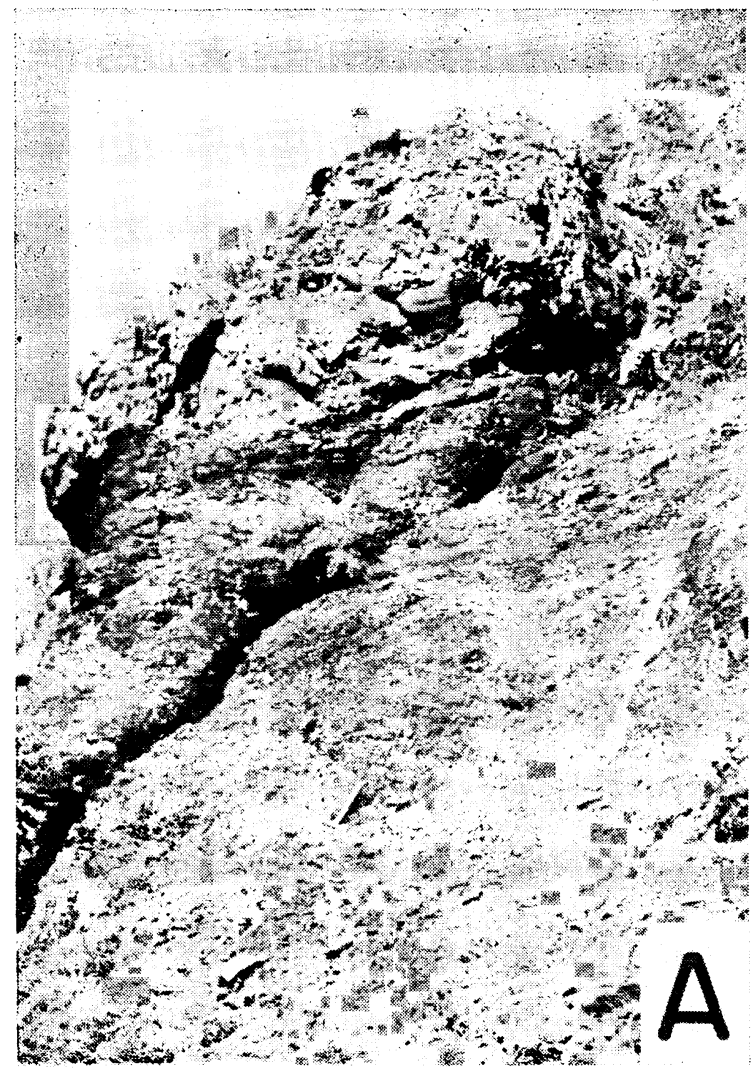

A. Silty shale with dispersed grit, cut at the top by a steep-sided channel containing bouldery conglomerate. Sample MF36 from sandy siltstone at this locality.

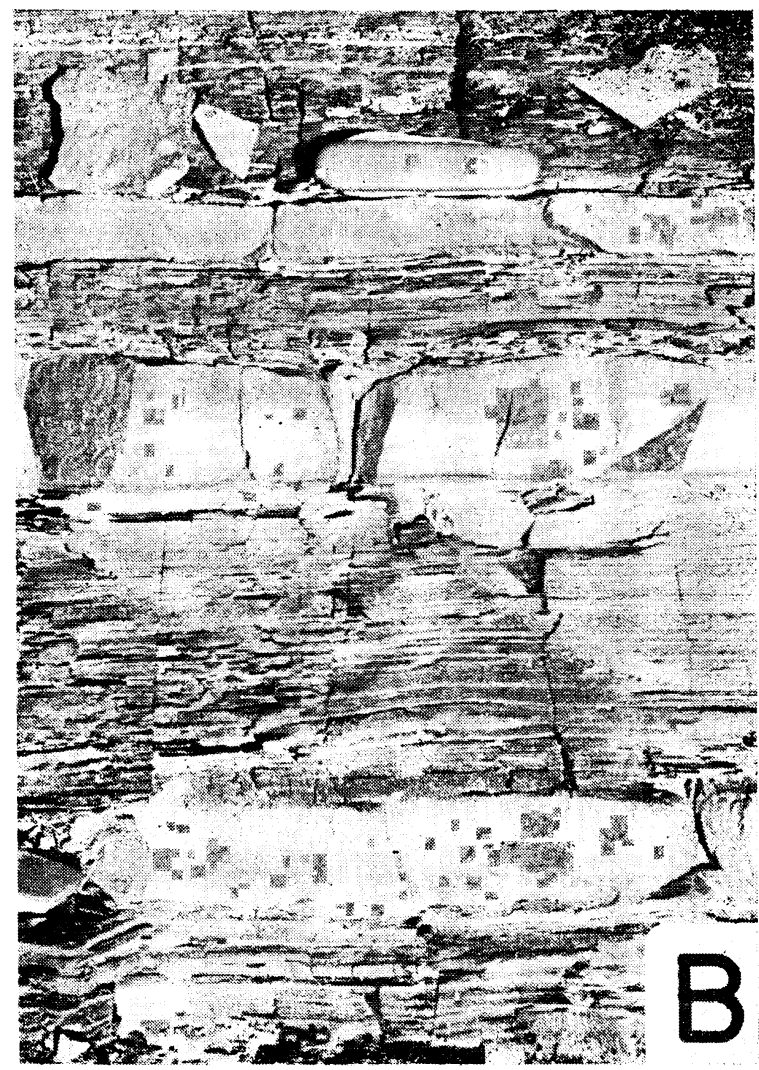

B. Rhythmically interbedded fine-grained sandstone and laminated siltstone. The lower two sandstone bed shows normal grading. The upper sandstone is laminated. Sample MF45 is from siltstone of this facies. 


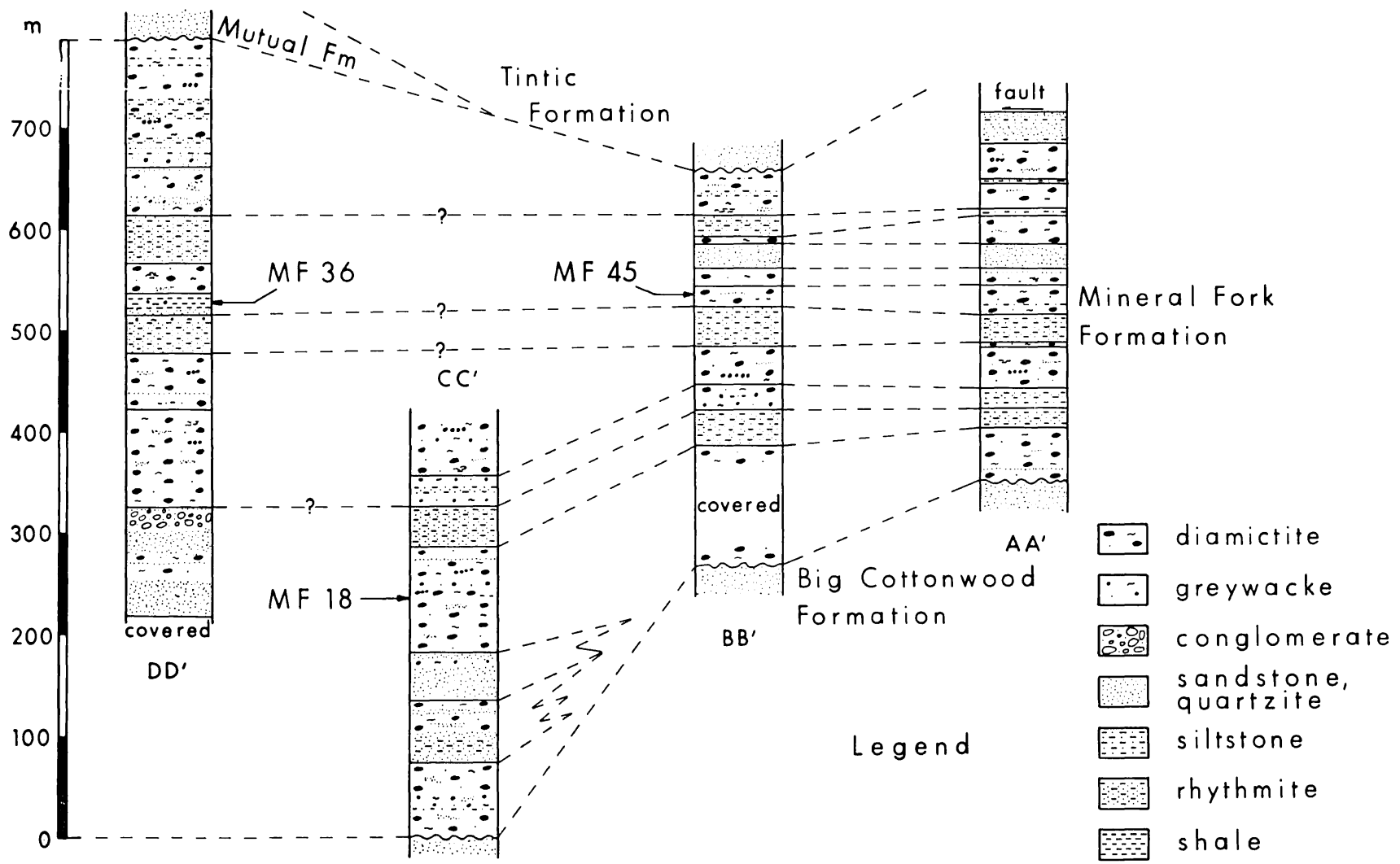

Fig. 4. Stratigraphy of the Mineral Fork Formation in the vicinity of Mineral Fork and location of microfossil samples. Tentative correlations between measured sections are indicated by dashed lines. 
entirely nonglaciogenic was expressed by Schermerhorn in 1974. In October, 1978, two of us (N.B. and S.M.A.) had the pleasure of examining Mineral Fork outcrops with Dr. Schermerhorn. He now agrees that there exists a glaciclastic component to the sediments, although he reserves judgement on the regional significance of the glaciation.

The presence of glacial sediment is suggested by: (1) poorly sorted, petrologically immature and heterogeneous sedimentary rocks (diamictite) containing a proportion of matrix grains having primary angularity and large lonestones of diverse provenance; (2) the occurrence in the diamictite of chert pebbles and cobbles with intersecting scratches and grooves, and rarely having pentagonal flatiron shapes; and (3) the rare occurrence in laminated beds of isolated pebbles and cobbles thought to have dropped from floating ice.

In the central Wasatch Mountains, the Mineral Fork Formation occupies two troughs eroded into the underlying Big Cottonwood Formation. One of these linear depressions ( $400 \mathrm{~m}$ deep) is exposed in two sections (separated by a thrust fault) north of Big Cottonwood Canyon. The other, from which the microfossil specimens were retrieved (figs. 1, 4), is $850 \mathrm{~m}$ deep and extends southward from Big Cottonwood Canyon to Little Cottonwood Canyon (see Crittenden, 1965a,b). The base of the northern trough can be seen at one locality in Mill B North Fork of Big Cottonwood Canyon. Here one finds erosional ridges up to $2 \mathrm{~m}$ high and grooves as much as $1 \mathrm{~m}$ long that run parallel to the ridges. These features are interpreted to be glacially striated roches moutonnées and support the idea that the troughs are valleys cut during glacial advance.

Ojakangas and Matsch (1976) compared the Mineral Fork Formation with Upper Pleistocene deposits of the northern Puget Sound Lowland, Wash. There, lobes from the Cordilleran Ice Sheet periodically reached the sea to produce a complex interfingering of basal till, water-laid till, outwash sand and gravel, dropstone deposits, and rock flour rich marine silt.

The rhythmically interbedded sandstone and laminated siltstone of the Mineral Fork Formation probably are not varves because of the lack of graded couplets. Well developed varves do not occur in the marine environment, and their absence from fine-grained interglacial deposits suggests marine deposition (Lindsey, 1971).

More detailed data supporting a glacial interpretation of the Mineral Fork Formation have been developed by one of us (N.B.) as part of a continuing investigation of the upper Precambrian sedimentary sequence of northwestern Utah. A full discussion of these data and their significance will be presented elsewhere. As the emphasis of this paper is primarily paleontological, it is sufficient here to summarize by reiterating that considerable evidence supports the glaciogenic interpretation for the Mineral Fork Formation. The Mineral Fork sediments accumulated at times beneath and immediately in front of the glaciers and at other times 
beneath the sea, which periodically inundated the valleys or fjords (?) during glacial retreat.

\section{ECOLOGICAL INTERPRETATION}

It is clear from the preceding discussion that the Mineral Fork sedimentary sequence reveals the source of the environmental stress inferred from the microfossil assemblage. Several factors might contribute to the stress on a fjord ecosystem during glacial or early post-glacial epochs.

1. Nutrient influx.-In an analysis of cores taken from periglacial Eight Lake in northern Alaska, Livingstone, Bryan, and Leahy (1958) found that during the early stages of glacial melting, the lake was characterized by high productivity and eutrophication. A similar correspondence of early deglaciation and a high productivity/eutrophic lake phase has been noted for Berry Pond, Mass., and other Late Pleistocene and Holocene lakes in North America (Whitehead and others, 1973). Although the precise causes of post-glacial eutrophication are complex and not clearly understood, many authors believe that the influx of nutrients eroded from newly exposed till and rock surfaces contributes significantly to the process (Livingstone, Bryan, and Leahy, 1958; Whitehead and others, 1973).

2. Salinity fluctuations.-Fluctuations in the rate of influx of glacial meltwater into a fjord would result in an environment of low and variable salinity.

3. Temperature.-The effect of low temperature on modern planktonic algal diversity in aquatic ecosystems is not marked (Livingstone, Bryan, and Leahy, 1958); however, the relatively diverse acritarch assemblages found in late Precambrian strata from many parts of the world may be warm water assemblages and, hence, restricted in a general way by temperature from contemporary periglacial environments.

Thus, it seems likely that the Mineral Fork environment was physically stressed due to salinity variations and low temperature associated with calving icebergs and meltwater entering the flooded depositional troughs. Nutrients leached from till and polished bedrock were abundant. Under such conditions it is reasonable to expect a small number of opportunistic species to expand rapidly to dominate the primary production level of the community. We interpret Bavlinella faveolata (as amended by Vidal, 1976a, to include all stages of the life cycle) as such an opportunistic taxon. Bavlinella has been identified in many Late Precambrian deposits but usually as a minor component of microfossil assemblages. For example, in Vidal's (1976a) analysis of a fossil microbiota from siltstones and shales of the Visingsö Formation in Sweden, he counted 2959 specimens of Trachysphaeridium laminaritum, 3040 of Octoedryxium truncatum, and 20,861 of Protosphaeridium laccatum, but only 16 individuals of Bavlinella faveolata. A relatively unimportant constituent of many temperate to tropical habitats, Bavlinella was able to capitalize on the glacially influenced environment of the Mineral Fork. 
The next question of importance is: Does the relationship between glacial environments and Bavlinella-dominated microfossil assemblages hold in places other than the Mineral Fork of Big Cottonwood Canyon in Utah? Available evidence suggests that it does. A microfossil assemblage contained in carbonaceous mudstones from Cold Canyon, North Ogden quadrangle, Utah (Cloud's loc. 2 of August 11, 1969, in Cloud, Moorman, and Pierce, 1975) is very similar in composition to the Mineral Fork biota. The Cold Canyon samples come from the informally named "formation of Perry Canyon" of Crittenden and Wallace (1973) and Sorensen and Crittenden (1976), a stratigraphic equivalent, in the thicker miogeoclinal section, to the Mineral Fork Formation. Like the Mineral Fork siltstones, these black mudstones accumulated in front of an ice margin. Widening the geographical scope, siltstones intercalated among tillites from the latest Precambrian Conception Bay Group exposed near Red Head, Newfoundland, contain a microbiota that like the Mineral Fork assemblage is almost completely dominated by Bavlinella (Knoll, unpub. data). Bavlinella-dominated microfossil assemblages are also associated with glaciogenic sedimentary sequences in East Greenland (Vidal, 1976b), Finnmark of northern Norway, southern Norway, South West Africa (Namibia), and Tasmania (Gonzalo Vidal, personal commun., 12 October 1978). Although these occurrences are suggestive, we do not yet have sufficient data to postulate a general relationship between Bavlinella. dominated acritarch assemblages and late Precambrian glaciogenic sequences. Other types of environmental stresses may have permitted local expansion of Bavlinella; conversely, not all glacially influenced environments may have been conducive to the growth of this particular organism. Still, ecology does tie together the micropaleontology and sedimentology of the Mineral Fork Formation in a satisfying way and in an interpretation that has relevance to other glaciogenic environments of the same approximate age.

\section{STRATIGRAPHIC QUESTIONS}

The age of the Mineral Fork Formation is poorly constrained by direct evidence. The underlying Big Cottonwood Formation was inferred by Crittenden, Stewart, and Wallace (1972) to be younger than the latest metamorphic overprint affecting the nearby Farmington Canyon Complex 1250 to 1400 m.y. ago. Stewart (1972) considered the Big Cottonwood Formation to be an approximate stratigraphic equivalent of the Uinta Mountain Group of northeastern Utah and adjacent Colorado. Uinta Mountain shales have been provisionally dated by Crittenden and Peterman (1975) as older than 950 m.y. (Rb/Sr rock age). The age of the Mutual Formation, which overlies the Mineral Fork sequence, is unknown, but the Tintic Quartzite in this region is latest Early or Middle Cambrian (Lochman-Balk, 1959, 1976).

Thus, the Mineral Fork Formation can be no older than 1250 m.y. (and perhaps 950 m.y.), nor can it be younger than 540 m.y. In the miogeocline of northwestern Utah, as much as several thousand meters 
of upper Precambrian strata overlie glacial beds presumably equivalent to the Mineral Fork. For this reason it seems unlikely that Mineral Fork beds are much younger than $650 \mathrm{~m} . \mathrm{y}$.

Glaciogenic rocks, lithologically similar to those of the Mineral Fork Formation, crop out in an equivalent stratigraphic position from Alaska to New Mexico (Stewart, 1972; Corbitt and Woodward, 1973). In northeastern Washington, greenstones overlying diamictite have been dated at 827 to 918 m.y. by Miller, McKee, and Yates (1973) using K/Ar analysis of plagioclase, pyroxene, and rock samples. Physical stratigraphic methods therefore suggest an approximate age of deposition of $800 \pm 150$ m.y. for the Mineral Fork Formation.

During the past $15 \mathrm{yrs}$, as the nature and extent of the Precambrian fossil record have come to be better appreciated, there have been increasing efforts to subdivide Proterozoic sedimentary sequences biostratigraphically. Degradation-resistant microfossils have proven to be valuable stratigraphic tools in clastic sequences, and particularly in the Soviet Union and in northern Europe, micropaleontologists have employed acritarchs in correlation. Bavlinella faveolata is widely distributed in latest Precambrian rocks and is considered by Vidal (1976a, 1977) to be a useful marker of the Vendian (650-570 m.y.).

If the presence of Bavlinella does indicate a Vendian or younger ${ }^{1}$ age, then its occurrence in the Mineral Fork Formation raises significant stratigraphic questions. There are four possible ways to interpret this situation:

1. The age for the Mineral Fork inferred from the physical stratigraphy and radiometric dating of presumably correlative diamictite sequences elsewhere in the Cordillera is correct, and the lower boundary of Bavlinella's stratigraphic range must be extended.

2. The early Vendian lower limit for Bavlinella is correct, and the late Precambrian Cordilleran glacial strata are younger than the $\mathrm{K} / \mathrm{Ar}$ dates would indicate.

3. Both the radiometric dates and the assumed lower limit of Bavlinella's range are somewhat in error; that is, there exists a range of possibilities intermediate between positions 1 and 2 .

4. Both the radiometric and the biostratigraphic data are accurate, and the presumption of stratigraphic equivalence for the Washington and Mineral Fork diamictites is incorrect, thus implying that at least two late Precambrian episodes of glaciation (or at least diamictite deposition) are recorded in rocks of the North American Cordillera.

Given the available evidence, it is impossible to choose unequivocally from this list of possibilities. In part this stems from a necessary circularity in the biostratigraphic interpretation of Precambrian fossils. The ages of Phanerozoic rock sequences are defined on the basis of fossils; how-

${ }^{1}$ Recently, Vidal (personal commun., October 1978) discovered specimens of Bavlinella in Cambrian shales from Scandinavia, where they are found with abundant baltisphaerids which do not occur in rocks antedating the Cambrian. 
ever, the stratigraphic framework for the Precambrian is based on field relations and isotopic dates, and biostratigraphic ranges must be fit into this structure. This is particularly true for Precambrian acritarchs. Thus, while one can say that species A has only been found in rocks of Vendian age, one can never aver with complete confidence that species A will not be found in some as yet unexamined Riphean sequence. The resulting system does provide a useful framework for biostratigraphic analysis, but its success depends on the continual refinement of range estimates.

The Mineral Fork Bavlinella assemblage unfortunately provides an excellent example of this methodological uncertainty. In 1977, Gonzalo Vidal wrote:

To the present I have processed a few thousands of Proterozoic and Lower Cambrian samples. So far, I have never found $B$. faveolata in typically Riphaean acritarch assemblages. On the contrary, it is always found with Vendian (or possibly Vendian) acritarch taxa.

Vidal's statement certainly would imply that the Cordilleran glacial strata are younger than current estimates indicate, but because of the peculiar facies of the Mineral Fork microbiota, the question of its age cannot be closed. The relationship between Bavlinella and glacial environments was discussed in an earlier section of this paper, and it is quite conceivable that Bavlinella did exist in pre-Vendian fjords fed by meltwater from Late Riphean glaciers. That is, the question of preVendian Bavlinella occurrences could be one of environment. Unfortunately, there exists at present no palynological data on bona fide preVendian late Precambrian glacial sequences, although such rocks exist.

Therefore, questions of age remain. Are the Cordilleran glacials younger than current estimates? Must the time range of one of the more useful biostratigraphic indices of the Late Precambrian be expanded? Hypothesis three - that the age inferred from $\mathrm{K} / \mathrm{Ar}$ dates on the Washington greenstones may be an overestimate, although the glacials may still be significantly pre-Vendian — is appealing; however, we emphasize that this view is speculative (albeit based on solid stratigraphic logic). Solution of the stratigraphic puzzle posed by the western North American glacial sequences will require further radiometric and palynological analyses. Micropaleontological investigation of Upper Riphean glaciogenic sequences from other continents will also be required to settle the question of Bavlinella's stratigraphic range.

\section{SUMMARY}

The microbiota of the Mineral Fork Formation provides one small example of the type of information that can be gleaned from organic walled microfossils preserved in clastic facies of Precambrian sedimentary sequences. In the present investigation, we have generally used the sedimentary sequence to suggest interpretations of the microfossils, but our study, in conjunction with the work of a number of European and Soviet colleagues, helps to demonstrate that Late Precambrian acritarchs can be useful in deriving important environmental and stratigraphic information about the rocks in which they are found. 


\section{ACKNOWLEDGMENTS}

We thank Gonzalo Vidal (Lund Univ.) and Clyde Goulden (Philadelphia Acad. Nat. Sci.) for helpful discussions and Karen Morrison (Univ. California Santa Barbara) for photographic assistance. Part of this research (N.B.) was funded by NSF grants ATM 74-24201 and EAR 77-06008 to J. C. Crowell (Univ. California Santa Barbara).

\section{REFERENCES}

Allison, C. W., and Moorman, M. A., 1973, Microbiota from the Late Proterozoic Tindir Group, Alaska: Geolegy, v. 1, p. 65-68.

Beck, S., 1963, Licht- und elektronmikroskopische Untersuchungen an einer sporenbildenden Cyanophycee aus dem Formkreis von Pleurocapsa fuliginosa Hauck: Flora, v. 153, p. 194-216.

Bloeser, B., Schopf, J. W., Horodyski, R. J., and Breed, W. J., 1976, Chitinozoans from the Late Precambrian Chuar Group of the Grand Canyon, Arizona: Science, v. 195 , p. 676-679.

Cloud, P., Moorman, M., and Pierce, D., 1975, Sporulation and ultrastructure in a Late Proterozoic cyanophyte: some implications for taxonomy and plant phylogeny: Quart. Rev. Biology, v. 50, p. 131-150.

Condie, K. C., 1967, Petrology of the Late Precambrian tillite (?) association in Northern Utah: Geol. Soc. America Bull., v. 78, p. 1317-1344.

Corbitt, L. L., and Woodward, L. A., 1973, Upper Precambrian (?) diamictite of Florida Mountains, southwestern New Mexico: Geol. Soc. America Bull., v. 84, p. 171-174.

Crittenden, M. D., Jr., 1965a, Geology of the Dromedary Peak quadrangle, Utah: U.S. Geol. Survey Geol. Quad. Map GQ-378. 1965b, Geology of the Mount Aire quadrangle, Salt Lake County, Utah: U.S. Geol. Survey Geol. Quad. Map GQ-379.

Crittenden, M. D., Jr., and Peterman, Z. E., 1975, Provisional Rb/Sr age of Precambrian Uinta Mountain Group, northeastern Utah: Utah Geology, v. 2, p. 75-77.

Crittenden, M. D., Jr., Schaeffer, F. E., Trimble, D. E., and Woodward, L. A., 1971, Nomenclature and correlation of sorse upper Precambrian and basal Cambrian sequences in western Utah and southeastern daho: Geol. Soc. America Bull., v. 82 , p. 581-602.

Crittenden, M. D., Jr., Sharp, B. J., and Calkins, F. C., 1952, Geology of the Wasatch Mountains east of Salt Lake City, Parleys Canyon to Traverse Range: Utah Geol. and Mineralog. Survey Guidebook to the Geology of Utah, no. 8, p. 1-37.

Crittenden, M. D., Jr., Stewart, J. H., and Wallace, C. A., 1972, Regional correlation of upper Precambrian strata in western North America: Internat. Geol. Cong. 24th, Montreal 1972, sec. 1, p. 334-341.

Crittenden, M. D., Jr., and Wallace, C. A., 1973, Possible equivalents of the Belt Supergroup in Utah, in Belt Symposium: Moscow, Idaho, Univ. of Idaho and Idaho Bur. Mines and Geology, v. 1, p. 116-138.

Ford, T. D., and Brced, W. J., 1973, The problematical Precambrian fossil Chuaria: Palaeontology, v. 16, p. 535-550.

Geitler, L., 1932, Cyanophyceac, in Kolkwitz, R., ed., Kryptogamenflora von Deutschland, Österreich and der Schweiz: Leipzig, Akad. Verlagsgesell., v. 14, 1196 p.

Hintze, F. F., Jr., 1913, A contribution to the geology of the Wasatch Mountains, Utah: New York Acad. Sci. Annals, v. 23, p. 85-143.

Hofmann, H. J., 1977, The problematic fossil Chuaria from the Late Precambrian Uinta Mountain Group, Utah: Precambrian Research, v. 4, p. 1-11.

Hofmann, H. J., and Aitken, J. D., 1979, Precambrian biota from the Little Dal Group, Mackenzie Mountains, northwestern Canada: Canadian Jour. Earth Sci., v. 16 , p. 150-166.

Hofmann, H. J., King, A. F., and Hill, J., 1979, Late Precambrian microfossils, southeastern Newfoundland: Canada Geol. Survey Paper 79-1 B, p. 83-98.

Horodyski, R. J., and Bloeser, B., 1978, 1400-Million-Year-Old shale facies microbiota from the Lower Belt Supergroup, Montana: Science, v. 199, p. 682-684.

Javor, B. J., and Mountjoy, E. W., 1976, Late Proterozoic microbiota of the Miette Group, southern British Columbia: Geology, v. 4, p. 111-119.

Knoll, A. H., Barghoorn, E. S., and Awramik, S. M., 1978, New microorganisms from the Aphebian Gunflint Iron Formation, Ontario: Jour. Paleontology, v. 52, p. 976-992. 
Knoll, A. H., and Golubic, S., 1979, Anatomy and taphonomy of a Precambrian algal stromatolite: Precambian Research, v. 10, p. 115-151.

Knoll, A. H., and Keller, F., 1979, Late Precambrian microfossils from the Walden Creek Group, Ocoee Supergroup, eastern Tennessee. Geol. Soc. America, Abs. with Programs, v. 11, p. 185.

Licari, G. R., and Cloud, P., 1969, Eucaryotic nannofossils in kerogens from the prePaleozoic Windermere Series of Alberta [abs.]: Geol. Soc. America Spec. Paper 121, p. 174-175.

Lindsey, D. A., 1971, Glacial marine sediments in the Precambrian Gowganda Formation at Whitefish Falls, Ontario (Canada): Palaeogeography, Palaeoclimatology, Palaeoecology, v. 9, p. 7-25.

Livingstone, D. A., Bryan, R., and Leahy, R. G., 1958, Effects of an arctic environment on the origin and development of freshwater lakes: Limnology Oceanography, v. 3 , p. 192-214.

Lochman-Balk, C., 1959, The Cambrian section in the central and southern Wasatch Mountains: Intermountain Assoc. Petroleum Geologists, 10th Ann. Field Conf., Guidebook to the geology of the Wasatch and Uinta Mountains transition area, p. 40-56.

1976, The Cambrian section of the central Wasatch Mountains, in Hill, J. G., ed., Symposium on geology of the Cordilleran hingeline: Rocky Mountain Assoc. Geologists, p. 103-108.

Miller, F. K., McKee, E. H., and Yates, R. G., 1973, Age and correlation of the Windermere Group in northeastern Washington: Geol. Soc. America Bull., v. 84, p. $3723-3730$.

Moorman, M., 1974, Microbiota of the Late Proterozoic Hector Formation, southwestern Alberta, Canada: Jour. Paleontology, v. 48, p. 524-539.

Ojakangas, R. W., and Matsch, C. L., 1976, The upper Precambrian Mineral Fork Tillite, Utah: A glacial and glaciomarine sequence: Geol. Soc. America Abs. with Prograins, v. 8, no. 6, p. 1035.

Peat, C. J., Muir, M. D., Plumb, K. A., McKirdy, D. M., and Norvick, M. S., 1978, Proterozoic microfossils from the Roper Group, Northern Territories: Australia Bur. Minerals Research Jour. Geology Geophyics, v. 3, p. 1-17.

Prakash, A. D., Skoglund, L., Rystad, B., and Jensen, A., 1973, Growth and cell-size distribution of marine planktonic algae in batch and dialysis cultures: Canada Fisheries Research Board Jour., v. 30, p. 143-155.

Roblot, M., 1963, Découverte de sporomorphes dans des sédiments antérieurs á 550 M.A. (Briovérien): Acad. Sci. Paris Comptes rendus, v. 256, p. 1557-1559.

1964, Sporomorphes du Precámbrian Normand: Rev. Micropaleontology, v. 7, p. $153-156$.

Ronov, A. B., 1968, Probable changes in the composition of sea water during the course of geological time: Sedimentology, v. 10, p. 25-43.

Schermerhorn, L. J. G., 1974, Late Precambrian mixtites: glacial and/or nonglacial?: Am. Jour. Sci., v. 274, p. 673-824.

Schopf, J. W., and Oehler, D. Z., 1976, How old are the eukaryotes?: Science, v. 193, p. $47-49$.

Sorensen, M. L., and Crittenden, M. 1)., Jr., 1976, Preliminary geologic map of the Mantua quadrangle and post of the Willard quadrangle, Box Elder, Weber, and Cache Countics, Utah: U.S. Geol. Survey Misc. Field Studies Map MF-720.

Stcwart, J. H., 1972, Initial deposits in the Cordilleran Geosyncline: evdience of a Late Precambrian (<850 m.y.) continental separation: Geol. Soc. America Bull., v. 83, p. 1345-1360.

Timofecv, B. V., 1959, The ancient flora of the Baltic regions and its stratigraphic significance: Trudy vsesoyuznogo neftyanogo naucho-issledovatelskogo geologorazvedochnogo Inst. (in Russian), no. 129, 350 p.

1969, Sphacromorphida of the Proterozoic: Leningrad, Akad. Nauk SSSR Izd. (in Russian), 146 p.

1973, Microphytofossils of the Precambrian of the Ukraine: Leningrad, Akad. Nauk SSSR Izd. (in Russian), 100 p.

Varney, P. J., 1976, Depositional environment of the Mineral Fork Formation (Precambrian), Wasatch Mountains, Utah, in Hill, J. G., ed., Symposium on geology at the Cordilleran hingeline: Rocky Mountain Assoc. Geologists, p. 91-102. 
Vidal, G., 1976a, Late Precambrian microfossils from the Visingsö Beds in southern Sweden: Fossils and Strata, no. 9, 57 p.

1976b, Late Precambrian acritarchs from the Eleonore Bay Group and Tillite Group in East Greenland: Grønlands Geol. Undersøgelse Rappt. Nr. 78, $19 \mathrm{p}$.

1977, Late Precambian microfossils: Gcol. Mag., v. 114, p. 393-394.

Volkova, N. L., 1968, Acritarcha of Precambrian and Lower Cambrian deposits of Estonia, in Problematics of Riphean and Cambrian layers of the Russian Platform, Urals, and Kazakhstan: Moscow, Acad. Nauk SSSR Geol. Inst., v. 188, p. 8-36.

Waiter, M. R., Oehler, J. H., and Ochler, D. Z., 1976, Megascopic algae 1300 million years old from the Belt Supergroup, Montana: A reinterpretation of Walcott's Helminthoidichnites: Jour. Paleontology, v. 50, p. 872-881.

Waterbury, J. B., and Stanier, R. Y., 1978, Patterns of growth and development in Pleurocapsalean cyanobacteria: Microbiology Rev., v. 42, p. 2-44.

Whitehead, D. R., Rochester, H., Rissing, S. W., Douglass, C. B., and Sheehan, M. C., 1973, Late glacial and post-glacial productivity changes in a New England pond: Science, v. 181, p. 744-747.

Whittaker, R. H., 1975, Communities and Ecosystems: New York, MacMillan, 385 p.

Ziegler, A. M., Walker, K. R., Anderson, E. J., Kauffman, E. G. Ginsburg, R. N., and James, N. P., 1974, Principles of Community Analysis: Miami, Univ. Miami Comparative Sedimentology Lab., p. 2.1-2.20. 